\title{
The evolutionary behavior of chromophoric brown carbon during ozone aging of fine particles from biomass burning
}

\author{
Xingjun Fan ${ }^{1,3}$, Tao Cao ${ }^{2,4}$, Xufang Yu${ }^{1}$, Yan Wang ${ }^{1}$, Xin Xiao ${ }^{1}$, Feiyue $\mathrm{Li}^{1,3}$, Yue $\mathrm{Xie}^{1}$, Wenchao $\mathrm{Ji}^{1}$, \\ Jianzhong Song ${ }^{2}$, and Ping'an Peng ${ }^{2}$ \\ ${ }^{1}$ College of Resource and Environment, Anhui Science and Technology University, Fengyang 233100, P. R. China \\ ${ }^{2}$ State Key Laboratory of Organic Geochemistry, Guangzhou Institute of Geochemistry, \\ Chinese Academy of Sciences, Guangzhou 510640, P. R. China \\ ${ }^{3}$ Anhui Province Key Laboratory of Biochar and Cropland Pollution Prevention, Bengbu 233400, P. R. China \\ ${ }^{4}$ University of Chinese Academy of Sciences, Beijing 100049, P. R. China
}

Correspondence: Jianzhong Song (songjzh@gig.ac.cn) and Xingjun Fan (fanxj@ahstu.edu.cn)

Received: 7 September 2019 - Discussion started: 14 November 2019

Revised: 8 March 2020 - Accepted: 26 March 2020 - Published: 21 April 2020

\begin{abstract}
Biomass burning (BB) emits large amounts of brown carbon $(\mathrm{BrC})$; however, the evolutionary behavior of $\mathrm{BrC}$ in $\mathrm{BB}$ emissions (BB $\mathrm{BrC}$ ) resulting from complex atmospheric processes is poorly understood. In this study, the transformation of contents and the chromophoric characteristics of $\mathrm{BrC}$ in smoke particles emitted by the burning of rice straw (RS), corn straw (CS), and pinewood (PW) under $\mathrm{O}_{3}$ aging are investigated. The $\mathrm{O}_{3}$ aging induced the reduction of light absorption and fluorescence for the $\mathrm{BB} \mathrm{BrC}$, suggesting the decomposition of chromophores and fluorophores. These changes were accompanied by a decrease in aromaticity, average molecular weight, and the light absorption capacity for the chromophores, as well as an increase in humification for the fluorophores. The excitation emission matrix combined with a parallel factor analysis revealed that protein-like components (C3) were predominantly decomposed by $\mathrm{O}_{3}$ aging, while the relative distribution of a humiclike component with highly oxygenated chromophores (C4) gradually increased. In general, the humic-like substances $(\mathrm{C} 1+\mathrm{C} 2+\mathrm{C} 4)$ were transformed to be the most abundant fluorophores for all the $\mathrm{BB} \mathrm{BrC}$ samples, which accounted for $84 \%-87 \%$ of the total fluorophores in final $\mathrm{O}_{3}$-aged $\mathrm{BB}$ BrC. Two-dimensional correlation spectroscopy (2D-COS) was performed on the synchronous fluorescence, which suggested that the RS and CS BrC exhibits the same susceptible fluorophores changes upon $\mathrm{O}_{3}$ aging. It showed that $\mathrm{O}_{3}$ firstly reacted with protein-like fractions $(263-289 \mathrm{~nm})$ and then with fulvic-like fractions $(333-340 \mathrm{~nm})$. In com-
\end{abstract}

parison, the changing sequence of susceptible fluorophores in the $\mathrm{PW} \mathrm{BrC}$ to $\mathrm{O}_{3}$ was in the order of fulvic-like fluorophores with shorter wavelengths $(309 \mathrm{~nm})$, protein-like fluorophores $(276 \mathrm{~nm})$, and fulvic-like fluorophores with longer wavelengths $(358 \mathrm{~nm})$. The 2D-FTIR-COS (2D-COS combined with FTIR) analysis showed conjugated $\mathrm{C}=\mathrm{O}$ and aromatic $\mathrm{C}=\mathrm{C}$ and $\mathrm{C}=\mathrm{O}$ groups were the most susceptible functional groups to $\mathrm{O}_{3}$ aging for all $\mathrm{BB} \mathrm{BrC}$. Moreover, it also revealed a consistent sequential change, which is in the order of aromatic $\mathrm{OH}$; conjugated $\mathrm{C}=\mathrm{O}$ groups and aromatic $\mathrm{C}=\mathrm{O}$; aromatic $\mathrm{COO}^{-}$; and finally lignin-derived $\mathrm{C}-\mathrm{C}, \mathrm{C}-\mathrm{H}$, and $\mathrm{C}-\mathrm{O}$ groups. Our results provide new insights into the evolutionary behavior of the chromophoric and fluorescent properties of $\mathrm{BB} \mathrm{BrC}$ during $\mathrm{O}_{3}$ aging, which are of great significance for better understanding the heterogeneous oxidation pathways of $\mathrm{BB}$-derived $\mathrm{BrC}$ in the atmospheric environment.

\section{Introduction}

Brown carbon (BrC), as a fraction of organic aerosols with effective light absorption properties, has been a research hotspot in the atmospheric carbonaceous aerosols field (Andreae and Gelencser, 2006; Laskin et al., 2015; Yan et al., 2018). BrC strongly absorbs solar radiation at short ultraviolet-visible wavelengths, which has been estimated to contribute $6 \%-28 \%$ of the total atmospheric aerosol absorp- 
tion (Chen et al., 2018; Chung et al., 2012; Feng et al., 2013; Liu et al., 2015). Owing to its significant effect on light absorption, $\mathrm{BrC}$ can affect both direct radiative forcing and atmospheric photochemistry (Mok et al., 2016; Jo et al., 2016). In addition, $\mathrm{BrC}$ may have an adverse effect on human health due to its capacity of enhancing the oxidative potential of atmospheric aerosols (Chen et al., 2019; Ma et al., 2018).

Atmospheric $\mathrm{BrC}$ arises from multiple sources, including biomass burning (BB), coal combustion, and secondary atmospheric chemical reactions (Bond, 2004; Chen et al., 2018; Fan et al., 2018; Hecobian et al., 2010; Saleh et al., 2013; Wang et al., 2018). Among them, BB is believed to be one of the important sources (Chen and Bond, 2010; Fan et al., 2016, 2018; Huo et al., 2018; Park and Yu, 2016). Recently, primary $\mathrm{BB} \mathrm{BrC}$ has been widely studied, which has provided deep insights into its BB source-dependent chemical and optical properties (Fan et al., 2016, 2018; Park and $\mathrm{Yu}, 2016)$. Moreover, both laboratory and field studies have demonstrated that atmospheric aging processes will lead to a transformation of the chemical composition and optical properties of $\mathrm{BB} \mathrm{BrC}$ once it is emitted into the atmosphere (Fan et al., 2019; Pillar et al., 2014, 2015, 2017; Saleh et al., 2013; Schnitzler and Abbatt, 2018; Sumlin et al., 2017; Wong et al., 2017, 2019; Zhong and Jang, 2014). The relevant processes mainly occur in either the atmospheric aqueous phase (Fan et al., 2019; Wong et al., 2017, 2019; Zhao et al., 2015), gas phase (Schnitzler and Abbatt, 2018; Sumlin et al., 2017; Zhong and Jang, 2014), or air-particle interface (Pillar-Little and Guzma, 2018, and references therein) with homogeneous or heterogeneous oxidation.

Most studies have investigated $\mathrm{BB} \mathrm{BrC}$ aging processes with a focus on aqueous-phase oxidations, such as photochemistry (Chang and Thompson, 2010; Zhao et al., 2015), dark OH-induced oxidation (G. T. Santos et al., 2016; P. S. Santos et al., 2016; Santos and Duarte, 2015), and carbonyl compound reactions with amines/ammonium sulfate (AS) (De Haan et al., 2017; Tang et al., 2016). The oxidation mechanisms and evolution of the optical properties of individual water-soluble organic compounds derived from BB emissions, such as levoglucosan (Holmes and Petrucci, 2006), aromatic acids (P. S. Santos et al., 2016), phenolic compounds (Lavi et al., 2017), nitrophenols (Hems and Abbatt, 2018; Lin et al., 2015), methylglyoxal (De Haan et al., 2017), and some other unsaturated carboxylic acids (Gallimore et al., 2011; Lee and Chan, 2007), have been well illustrated. The results suggest that the chromophoric characteristics of aged $\mathrm{BrC}$ are highly variable across different precursors and oxidation conditions. Many recent laboratory simulation studies have also tentatively explored the evolution and oxidation mechanisms of water-soluble $\mathrm{BB} \mathrm{BrC}$ in the aqueous phase with or without light (Fan et al., 2019; Wong et al., 2017, 2019). These studies have observed that $\mathrm{BB} \mathrm{BrC}$ undergoes both enhancement and bleaching, but a significant bleaching of $\mathrm{BrC}$ dominantly occurs over a long aging time. However, these results are far from definitively pronouncing the evolutionary behavior of $\mathrm{BB} \mathrm{BrC}$, mainly because of the high complexity of BB emission (i.e., nonpolar and polar organic compounds, soot particles) and atmospheric oxidants (i.e., $\mathrm{O}_{3}, \mathrm{NO}_{2}, \mathrm{OH}$ radicals).

The heterogeneous oxidations are also important pathways to form or bleach $\mathrm{BrC}$, which have been widely studied for the aging of soot and individual organic compounds by $\mathrm{OH}$, $\mathrm{O}_{3}, \mathrm{NO}_{x}, \mathrm{SO}_{2}$, and $\mathrm{HONO}$ (Baduel et al., 2011; Gallimore et al., 2011; He et al., 2017; Li et al., 2013, 2015, 2017; PillarLittle and Guzman, 2018, and references therein). Among them, the $\mathrm{O}_{3}$ aging simulations have been widely conducted, mainly because of $\mathrm{O}_{3}$ is not only a significant pollutant but also an important oxidant in the atmosphere (Chapleski et al., 2016; Chi et al., 2018; $\mathrm{Li}$ et al., 2018). The $\mathrm{O}_{3}$ oxidation of soot particles generally changes their physicochemical properties (i.e., water solubility, hygroscopicity, size, oxidative potential, and morphology), as well as forms new chromophoric compounds (Decesari et al., 2002; Li et al., 2013; Zhu et al., 2019). In addition, the $\mathrm{O}_{3}$ oxidation of organic compounds, such as humic-like substances (HULISs), catechol, and its substituted ones, commonly leads to competitive fragmentation and functionalization of chromophores (Baduel et al., 2011; D'Anna et al., 2009; Pillar et al., 2014, 2015, 2017; Sun et al., 2019). To date, however, there has been no systematic investigation on the evolutionary behavior of bulk BrC, especially in terms of its chromophoric characteristics, via heterogeneous $\mathrm{O}_{3}$ oxidation of complex $\mathrm{BB}$ emissions.

The objective of this study is to comprehensively investigate the evolutionary behavior of fine particulate chromophoric $\mathrm{BrC}$ produced by $\mathrm{BB}$ during the $\mathrm{O}_{3}$ aging process. For this purpose, the $\mathrm{O}_{3}$ aging of three types of BB smoke particles emitted from rice straw (RS), corn straw (CS), and pinewood (PW) is conducted in a reactor. Then, the levels and chromophoric characteristics of fresh and aged $\mathrm{BrC}$ are determined with a total organic carbon (TOC) analysis, ultraviolet-visible (UV-Vis) spectroscopy, an excitation-emission matrix (EEM) fluorescence spectroscopy, and Fourier transform infrared (FTIR) spectroscopy. Furthermore, the $\mathrm{O}_{3}$ aging mechanism of $\mathrm{BB} \mathrm{BrC}$ is explored using EEM combined with a parallel factor analysis (PARAFAC) and a two-dimensional correlation analysis (2D-COS) applied on the synchronous fluorescence spectra and FTIR. These approaches have allowed us to investigate the levels and types of independent underlying fluorophores of BrC (Chen et al., 2016b; Fan et al., 2019) and explore the dynamic spectral behavior of chromophores and molecular structures of BrC (Fan et al., 2019; Duarte et al., 2015). Our results have great importance in terms of furthering source apportionment of atmospheric $\mathrm{BrC}$ and of improving the accuracy of predicting their effects in atmospheric environments and on climate change. 


\section{Experimental section}

\subsection{Preparation of the BB smoke particles}

The BB smoke particles were prepared in a laboratory sampling system, which was described in detail in our previous study (Fan et al., 2018). The burning experiments were conducted without any control conditions, which is most similar to a natural BB process. Briefly, small pieces of RS, CS, and PW biomass materials were placed on stainless-steel mesh in a combustor and then ignited with an electronic gas lighter. The resulting smoke was introduced into a mixing chamber with diluted air, and the fine smoke particles were collected on quartz filters (Whatman, $\varnothing 90 \mathrm{~mm}$ ) using a $\mathrm{PM}_{2.5}$ sampler (Tianhong Intelligent Instrument Plant, Wuhan, China) at a flow rate of $80 \mathrm{~L} \mathrm{~min}^{-1}$. Finally, BB particles were obtained from each of the three fuels.

\subsection{Ozone aging of BB smoke particles}

The $\mathrm{O}_{3}$ aging experiments of the $\mathrm{BB}$ smoke samples were conducted in a self-designed reactor. A schematic diagram of the ozone aging reactor is illustrated in Fig. 1. The construction of the reactor and its operation are described in detail in Sect. $\mathrm{S} 1$ of the Supplement. For $\mathrm{O}_{3}$ aging, the sampled BB smoke particle filters were first cut into pieces (area of each piece is equal to $1.5 \mathrm{~cm}^{2}$ ) and then uniformly spread in a glass dish $(\Phi=90 \mathrm{~mm})$ before being exposed in an $\mathrm{O}_{3}$ environment in the principal reactor. During the aging process, the temperature, relative humidity $(\mathrm{RH})$, and $\mathrm{O}_{3}$ concentration in the principal reactor were maintained at $25^{\circ} \mathrm{C}$, $40 \%$ and $70 \mathrm{ppm}$, respectively. To avoid any photolysis of $\mathrm{O}_{3}$ and any photochemical reactions, all components in the reactor were wrapped with aluminum foil. Additionally, control experiments were conducted, but no variations of the chromophoric $\mathrm{BrC}$ were observed when there was no ozone introduced (Sect. S2, Figs. S1-S2 in the Supplement).

It should be noted that some gas-phase artifacts (i.e., semivolatile and intermediate-volatility organic compounds) possibly adsorbed on the quartz filters during sampling (Geller et al., 2006; Parshintsev et al., 2011). However, the amounts of these adsorbed organic artifacts on the filters are very small $\left(0.48-0.98 \mu \mathrm{gC} \mathrm{cm}{ }^{-2}\right.$ ) (Arhami et al., 2006; Subramanian et al., 2004) and are much lower than the amounts of the OC fraction $\left(\sim 250-750 \mu \mathrm{gC} \mathrm{cm}^{-2}\right)$ in fresh BB smoke samples. Therefore, the potential contributions from $\mathrm{O}_{3}$ oxidation of gas-phase artifacts on filters to $\mathrm{BB} \mathrm{BrC}$ can be neglected.

\subsection{Water-soluble BrC extraction}

At each designed exposure time $(0,1,2,4,8,12$, and $24 \mathrm{~h})$, three pieces of smoke filter for each BB sample were taken out and immersed in ultrapure water. After extracting with sonication for $30 \mathrm{~min}$, the extracts were filtered through a $0.22 \mu \mathrm{m}$ polytetrafluoroethylene syringe filter (Jinteng, Tian-

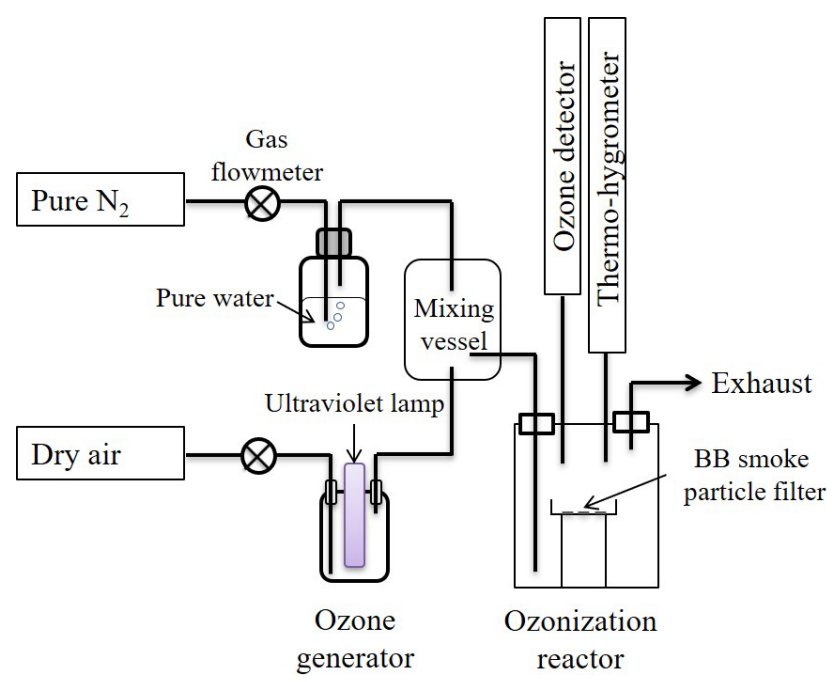

Figure 1. The experimental apparatus.

jin, China). The filtrates obtained were designated as watersoluble BrC.

\subsection{Analytical techniques}

The organic carbon (OC) content of the fresh and aged water-soluble $\mathrm{BB} \mathrm{BrC}$ samples was measured using a total organic carbon analyzer (TOC-VCPN, Shimadzu, Kyoto, Japan). The UV-Vis absorption spectra were obtained using a spectrophotometer (UV-2600, Shimadzu, Kyoto, Japan) at wavelengths ranging from 200 to $700 \mathrm{~nm}$. The synchronous fluorescence (SF) spectra were measured using a F-4600 fluorescence spectrometer (Hitachi, Tokyo, Japan) at excitation wavelengths ranging from 200 to $400 \mathrm{~nm}$ with a constant offset $(\Delta \lambda=60 \mathrm{~nm})$. The EEM spectra were also recorded using the F-4600 fluorescence spectrometer, and the scanning ranges were set to $220-400 \mathrm{~nm}$ for excitation and 290 $520 \mathrm{~nm}$ for emission, with a $5 \mathrm{~nm}$ interval. The scanning speed was set to $12000 \mathrm{~nm} \mathrm{~min}^{-1}$. Ultrapure water was used as blanks to correct the sample UV-Vis, SF, and EEM spectra. In addition, portions of the sample solutions were freezedried before the FTIR analysis. The FTIR spectra (4000$400 \mathrm{~cm}^{-1}$ ) were recorded at room temperature using a Nicolet iS10 FTIR spectrometer (Thermo, USA), and each spectrum was obtained after 64 scans with $4 \mathrm{~cm}^{-1}$ resolution. To describe the aging behavior of the $\mathrm{BB} \mathrm{BrC}$, some useful optical parameters, including the specific UV absorbance at $254 \mathrm{~nm}\left(\mathrm{SUVA}_{254}\right)$ (Fan et al., 2016), the absorption Ångström exponent (AAE) (Fan et al., 2016; Cheng et al., 2016; Huo et al., 2018; Park and Yu, 2016), mass absorption efficiencies (MAE 365 ) (Chen et al., 2016a; Fan et al., 2016; Huo et al., 2018; Park and Yu, 2016), and the humification index (HIX) (Qin et al., 2018), were comparatively analyzed. Their calculation protocols are described in detail in Sect. S3. 


\subsection{Parallel factor analysis}

PARAFAC was performed using MATLAB R2014a (MathWorks, USA) with the DOMFluor toolbox following the procedure introduced by Stedmon and Bro (2008). PARAFAC was computed using two- to seven-component models with nonnegativity constraints, and a four-component model was split-half validated on both halves using 63 distinct EEMs for all $\mathrm{BB} \mathrm{BrC}$ samples. It is noted that all EEMs were normalized to the area under the Milli-Q water Raman peak $(E x=350 \mathrm{~nm}, \mathrm{Em}=365-430 \mathrm{~nm})$, which was collected on the same day to produce corrected fluorescence intensities in Raman units (Lawaetz and Stedmon, 2009). Furthermore, the relative levels of the individual fluorophores were evaluated using the corresponding maximum fluorescence intensity $\left(F_{\max }\right)$ (Zhang et al., 2014; Matos et al., 2015).

\subsection{D-COS}

The SF spectra (200-400 nm) and FTIR spectra (1800$1000 \mathrm{~cm}^{-1}$ ) of each type of $\mathrm{BrC}$ were analyzed using 2D$\mathrm{COS}$, with the oxidation time as the perturbation variable. The calculations were performed using the 2D Shige software (Shigeaki Morita, Kwansei Gakuin University, Japan, 2004-2005). Details of the algorithm adopted in the software can be found in previous studies (Duarte et al., 2015; Jin et al., 2018; Hur and Lee, 2014). Finally, the synchronous and asynchronous maps were plotted by using the OriginPro 2018 software (OriginLab, USA).

\section{Results and discussion}

\subsection{Changes in water-soluble BrC levels in BB smoke particles}

Changes in the water-soluble organic carbon (WSOC) content of $\mathrm{BrC}$, calculated as $\mathrm{WSOC}_{[t]} / \mathrm{WSOC}_{[0]}$, for three types of $\mathrm{BB}$ smoke particles during the $\mathrm{O}_{3}$ aging process are shown in Fig. 2a. An initial rapid increase $(0-2 \mathrm{~h})$ and a final slight decrease $(8-24 \mathrm{~h})$ in WSOC for the three types of aged BB-produced smoke particles can be observed. However, some apparent differences were also identified for the three BB samples from 2 to $8 \mathrm{~h}$. During this period, the WSOC $_{[t]} / \mathrm{WSOC}_{[0]}$ values first decreased from 1.05 and 1.07 after $2 \mathrm{~h}$ to 0.99 and 1.04 after $4 \mathrm{~h}$ and then increased to 1.06 and 1.09 after $8 \mathrm{~h}$ for the RS and CS samples, respectively. In comparison, the $\mathrm{WSOC}_{[t]} / \mathrm{WSOC}_{[0]}$ values increased from 1.16 after $2 \mathrm{~h}$ to 1.22 after $4 \mathrm{~h}$ and then decreased to 1.18 after $8 \mathrm{~h}$ for the PW samples.

According to previous studies, the $\mathrm{O}_{3}$ oxidation of soot particles could produce some new WSOC fractions (Decesari et al., 2002; Li et al., 2015), and $\mathrm{O}_{3}$ may also destroy the $\mathrm{C}=\mathrm{C}$ bonds within weakly and even nonpolar organic compounds to generate newly highly hydrophilic Ocontaining functional components mainly through oxygen

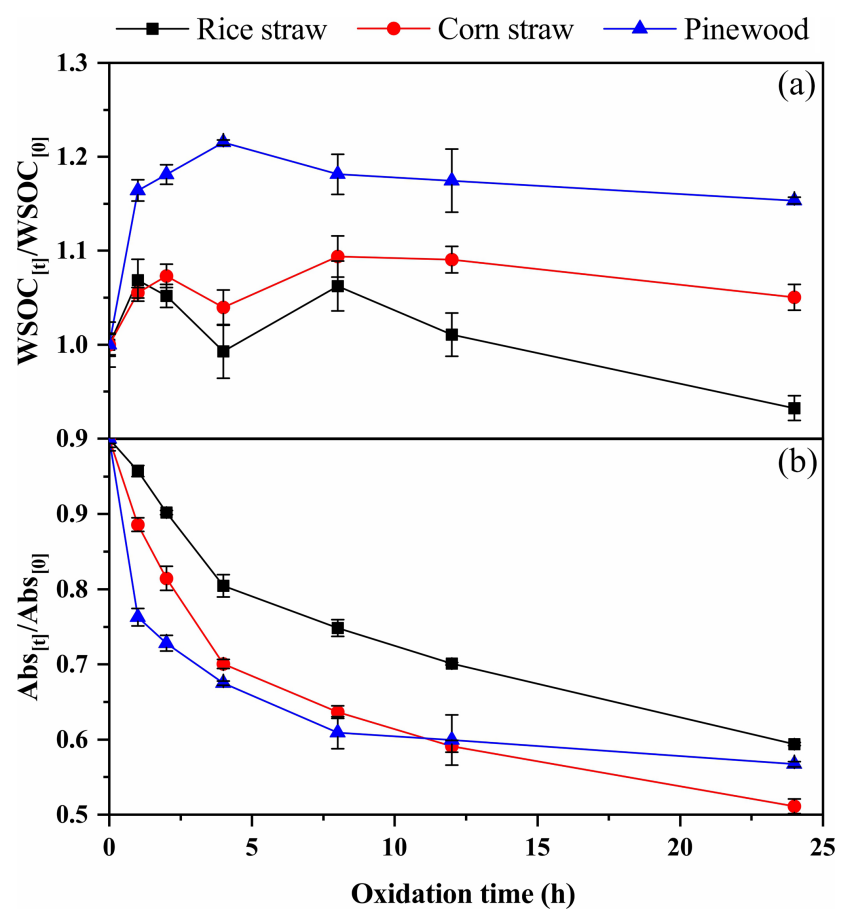

Figure 2. Dynamic variations of (a) WSOC content and (b) light absorption at a wavelength of $365 \mathrm{~nm}$ by the $\mathrm{BB} \mathrm{BrC}$ during the ozone aging process.

addition (i.e., carboxyl, hydroxyl, carbonyl, and phenol-OH groups) (Baduel et al., 2011). On the other hand, $\mathrm{O}_{3}$ could lead to $\mathrm{C}-\mathrm{C}$ bond cleavage within $\mathrm{OC}$ fractions to produce many volatile species, such as volatile organic compounds, $\mathrm{CO}$, and $\mathrm{CO}_{2}$, resulting in a loss of carbon mass (D'Anna et al., 2009). Due to the complex composition of BB emissions, the formation and decomposition of WSOC simultaneously occurs, and its composition dynamically changes. The initial rapid increase in WSOC content indicates that the formation of WSOC from the oxidation of the soot particles is likely the dominant reaction, and the observable decreasing trends of WSOC content might indicate that the amount being formed is unable to compensate for the amount that decomposes.

Changes in the total absorption at $365 \mathrm{~nm}$ (abs365) were investigated to illustrate the evolution of the chromophores in $\mathrm{BB} \mathrm{BrC}$ during the $\mathrm{O}_{3}$ aging process (Fig. 2b). The abs 365 values of $\mathrm{BrC}$ for the three $\mathrm{BB}$ smoke samples all gradually decreased with an increase in the aging time. As shown in Fig. $2 b$, a $41 \%-49 \%$ decrease in $\operatorname{abs}_{365}$ was seen for $24 \mathrm{~h}$ of $\mathrm{O}_{3}$ aging, indicating that the $\mathrm{BB} \mathrm{BrC}$ underwent significant bleaching. Given that some increase in the WSOC content was observed during the $\mathrm{O}_{3}$ aging process, the decreased abs365 may have been driven by a loss of highly absorbent WSOC and/or the formation of nonabsorptive/weakly absorptive WSOC fractions (Eugene et al., 2016; Lavi et al., 2017; Pillar et al., 2014, 2015; Rincón et al., 2009, 2010; Xia et al., 2018). This was consistent with the previous findings 
that the bleaching of BB-derived chromophores, such as oxocarboxylic acids and oxy-aromatics, generally resulted in formation of non-light-absorbing compounds, such as aliphatic mono- or polycarboxylic acids, containing alcohol $-\mathrm{OH}$, aldehyde $-\mathrm{C}(\mathrm{H})=\mathrm{O}$, and ether $-\mathrm{O}-$ groups (Eugene et al., 2016; Lavi et al., 2017; Pillar et al., 2014, 2015; Rincón et al., 2009, 2010; Xia et al., 2018). Moreover, the changes in $\mathrm{abs}_{365}$ for the three types of $\mathrm{BB} \mathrm{BrC}$ also exhibited some differences. The PW BrC presented higher degrees of bleaching than the CS and $\mathrm{RS} \mathrm{BrC} \mathrm{(Fig.} \mathrm{2b).} \mathrm{This} \mathrm{suggests} \mathrm{that} \mathrm{the}$ bleaching of chromophoric $\mathrm{BrC}$ within $\mathrm{PW}$ smoke particles during $\mathrm{O}_{3}$ aging is much more likely to occur than for CS and RS smoke particles.

\subsection{Variations of the chromophoric characteristics of BrC}

In the present study, $\mathrm{SUVA}_{254}$, HIX, $\mathrm{MAE}_{365}$, and AAE were investigated to characterize the evolution of the aromaticity, humification degree, and light-absorbing properties of $\mathrm{BB} \mathrm{BrC}$ during $\mathrm{O}_{3}$ aging. As shown in Fig. 3a, the BB BrC SUVA 254 values gradually declined, especially during the first hour, implying a significant decrease in aromaticity during $\mathrm{O}_{3}$ aging. This may be attributed to the decomposition of aromatic species and/or the formation of many more hydrophilic organic compounds with weak-lightabsorption or even non-light-absorption properties. The finding agreed well with the observations that the $\mathrm{O}_{3}$ oxidation of BB-derived chromophores (i.e., oxy-aromatics) could lead to cleavage of aromatic bonds into polyfunctional lowmolecular-weight carboxylic acids (Pillar et al., 2014, 2015, 2017). The noticeable HIX increases seen for the three types of $\mathrm{BB} \mathrm{BrC}$ indicate that the $\mathrm{O}_{3}$ aging may strongly decompose the protein-like fluorophores, probably phenolic compounds (Chen et al., 2016a), to form polyhydroxylated aromatic species or newly humic-like fluorophores (Pillar et al., 2014, 2015, 2017; Decesari et al., 2002; Li et al., 2013) (Fig. 3b). For example, $\mathrm{O}_{3}$ oxidation of phenolic compounds could form polyhydroxylated aromatic compounds with absorption redshift, which might lead to their HIX values increasing (Lavi et al., 2017; Magalhães et al., 2017; Pillar et al., 2015; Rincón et al., 2009, 2010). There seems to be contradictions between the results of the $\mathrm{SUVA}_{254}$ and HIX analyses, but together they are reasonable. It is known that SUVA $_{254}$ reflects the average aromaticity of entire WSOC fractions (Fan et al., 2016, 2018), which can be greatly reduced by weakly/non-light-absorbing organic compounds formed during $\mathrm{O}_{3}$ aging. However, HIX represents the humification characteristics of fluorophores within aged $\mathrm{BrC}$ (Qin et al., 2018), of which the influence of nonchromophores is excluded.

The $\mathrm{MAE}_{365}$ values of the $\mathrm{BB} \mathrm{BrC}$ showed a gradual decline as a function of oxidation time (Fig. 3c), giving rise to the $\mathrm{MAE}_{365}$ values of the $24 \mathrm{~h}$ aged $\mathrm{BB} \mathrm{BrC}$ being reduced by a factor of 1.6-2.2. This suggests that the absorp-

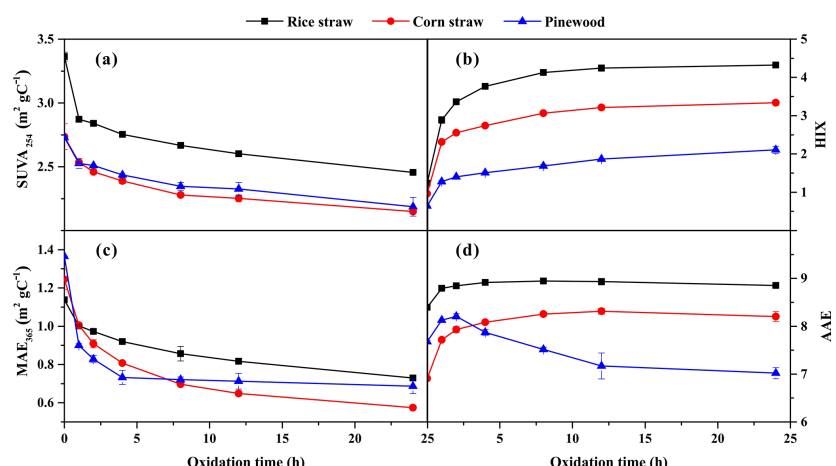

Figure 3. Dynamic variations of (a) $\mathrm{SUVA}_{254}$, (b) HIX, (c) $\mathrm{MAE}_{365}$, and (d) AAE of RS, CS, and PW smoke water-soluble $\mathrm{BrC}$ during the ozone aging process.

tion efficiency of $\mathrm{BrC}$ was weakened by the $\mathrm{O}_{3}$ aging, which greatly resembles the bleaching behavior of BB-derived $\mathrm{BrC}$ induced by photochemical oxidation and even complex realworld atmospheric processes (Chen et al., 2018; Kumar et al., 2018). For example, $\mathrm{OH}$ radical oxidation of woodburning emissions led to the mass absorption cross section at $370 \mathrm{~nm}$ of $\mathrm{BrC}$ declining by up to 2.3 times (Kumar et al., 2018). The BB BrC AAE values were observed to change during $\mathrm{O}_{3}$ aging as well (Fig. $3 \mathrm{~d}$ ). The $\mathrm{RS}$ and $\mathrm{CS}$ BrC AAE values generally increased as the $\mathrm{O}_{3}$ oxidation proceeded, suggesting that the light absorption of aged $\mathrm{BrC}$ exhibited a stronger wavelength dependence than fresh $\mathrm{BrC}$. This result is consistent with the behavior of $\mathrm{BB}$-derived $\mathrm{BrC}$ under photochemically aged processes reported in previous studies (Rincón et al., 2010; Saleh et al., 2013). It is noted that the PW BrC AAE values increased during the first $2 \mathrm{~h}$ but gradually declined during the next oxidation period. This behavior might be ascribed to the chromophores in crop straw and woodburning-produced $\mathrm{BrC}$ fractions having some differences in their respective compositions, which can be seen in the UV-Vis (Fig. S3) and SF spectra (Fig. S4) as well as those presented in previous studies (Fan et al., 2016, 2018).

\subsection{EEM and PARAFAC}

As shown in Figs. S5-S7, all the initial EEMs of the BB BrC display two apparent peaks, which are located in the range of $\lambda_{\mathrm{ex}} / \lambda_{\mathrm{em}}=230-240 \mathrm{~nm} / 365-390 \mathrm{~nm}$ and 260 $270 \mathrm{~nm} / 360 \mathrm{~nm}$. These two peaks are usually assigned to tyrosine-like compounds and tryptophan-like compounds, respectively, which are widely found in water-soluble organic matter (WSOM) and humic-like substances (HULISs) in BB aerosols (Fan et al., 2016; Huo et al., 2018), atmospheric aerosols, and rainwater (Qin et al., 2018; Santos et al., 2012). During the $\mathrm{O}_{3}$ aging process, these two fluorescence peaks in the BB BrC EEMs gradually shifted to longer-wavelength regions as the oxidation time increased. After $24 \mathrm{~h}$ of $\mathrm{O}_{3}$ aging, the above two peaks had almost disappeared and 
were replaced by the appearance of two apparent peaks in the range of $\lambda_{\text {ex }} / \lambda_{\text {em }}=240-250 \mathrm{~nm} / 400-425 \mathrm{~nm}$ and 280 290/390-400 nm for the three BB BrC samples (Figs. S5S7). These two peaks are usually assigned to humic-like fluorophores (Qin et al., 2018; Santos et al., 2009, 2012), suggesting the formation of new fluorophores in the aged $\mathrm{BB}$ $\mathrm{BrC}$. It is obvious that the resulting spectral characteristics are very similar to those of HULISs and WSOM in atmospheric aerosols and rainwater (Qin et al., 2018; Santos et al., 2009, 2012). Therefore, it can be concluded that $\mathrm{O}_{3}$ aging leads to a significant transformation of $\mathrm{BB} \mathrm{BrC}$, from dominant protein-like fluorophores within fresh $\mathrm{BB} \mathrm{BrC}$ to dominant humic-like fluorophores within aged $\mathrm{BB} \mathrm{BrC}$.

Quantified variations of the independent fluorophores can be revealed with EEM-PARAFAC. On the basis of a comparison of the PARAFAC-derived components for the atmospheric WSOM and HULISs (Chen et al., 2016a, b), BBproduced WSOM and HULISs (Huo et al., 2018), biocharand compost-produced dissolved organic matter (DOM) (Jamieson et al., 2014; Huang et al., 2018), and four fluorescent components were identified for the fresh and $\mathrm{O}_{3}$ aged BB BrC extracts. Their profiles and the corresponding assignments are shown in Fig. $4 \mathrm{a}$ and Table $\mathrm{S} 1$ in the Supplement, respectively. In general, these four individual fluorophores can be attributed to long-wavelength humic-like chromophores (HULIS-1, C1), short-wavelength humic-like chromophores that are less oxygenated (HULIS2, C2) and highly oxygenated (HULIS-3, C4), and proteinlike or phenol-like organic matter (PLOM, C3) (Chen et al., 2016a, b; Gao et al., 2017; Huang et al., 2018; Huo et al., 2018; Jamieson et al., 2014). It is noted that HULIS1,2 , and 3 are commonly found in the EEMs of HULISs and WSOM in atmospheric aerosols and rainwater (Chen et al., 2016b; Matos et al., 2015), which are expected to consist of fluorophores with strong aromaticity and large molecular sizes. PLOM is mainly comprised of the fluorophores having a similar position of fluorescence peaks to proteins, which generally include nitrogen-containing compounds (e.g., atmospheric amines and amides) and also nonnitrogen-containing species (e.g., phenol- and naphthalenelike substances) (Chen et al., 2016a; Fan et al., 2016; Huo et al., 2018). It is noted that the identified PLOM spectra of the $\mathrm{O}_{3}$-aged $\mathrm{BrC}$ resemble to those of fresh $\mathrm{BrC}$, suggesting protein-like and/or phenol-like substances are important fluorophores within both the fresh and aged BB-produced $\mathrm{BrC}$.

The quantitative analysis of the PARAFAC-derived components of the $\mathrm{BB} \mathrm{BrC}$ upon $\mathrm{O}_{3}$ aging are displayed in Fig. S8. It can be seen that the $\mathrm{O}_{3}$ aging caused significant quenching for components $\mathrm{C} 1-\mathrm{C} 3$ for all the $\mathrm{BB} \mathrm{BrC}$ samples, in which the quenching of $\mathrm{C} 3$ is the most dominant, with a degree range of $71 \%$ to $94 \%$. These findings suggest that the PLOM is susceptible to $\mathrm{O}_{3}$ aging. Noteworthy, the component $\mathrm{C} 4$ exhibits a gradual increase with $\mathrm{O}_{3}$ aging for the RS and CS BrC. This suggests that HULIS-3 is generated accompanied by the decomposition of PLOM,
HULIS-1, and HULIS-2 for crop straw burning BrC. In comparison, HULIS-3 (C4) presented an obvious decrease for the PW $\mathrm{BrC}$, indicating that all the fluorophores in the samples were susceptible to $\mathrm{O}_{3}$ aging. The variations in the proportional distribution of the independent components during $\mathrm{O}_{3}$ aging can be observed in Fig. $4 \mathrm{~b}$. In terms of the proportion of HULIS-1 (C1), the $\mathrm{BrC}$ samples during $\mathrm{O}_{3}$ aging presented relatively higher values than the fresh ones, but there were no significant differences among the aged samples. The proportion of PLOM (C3) within the BB BrC gradually declined during $\mathrm{O}_{3}$ aging, where the total decrease was from $37 \%$ to $16 \%$ for RS, $45 \%$ to $16 \%$ for CS, and $51 \%$ to $13 \%$ for PW. In comparison, the proportion of HULIS3 (C4) gradually increased from $0 \%$ to $16 \%$ for RS, $11 \%$ to $31 \%$ for CS, and $24 \%$ to $51 \%$ for PW. Taken together, the distributions of the humic-like fluorophores (HULIS-1, 2,3 ) accounted for $84 \%-87 \%$ of the aged $\mathrm{BB} \mathrm{BrC}$, which is much higher than the range $49 \%-63 \%$ observed for the initial fresh samples. It had been revealed that the $\mathrm{O}_{3}$ oxidation of oxy-aromatics could produce polyhydroxylated aromatics with light absorption toward longer wavelengths (Lavi et al., 2017; Magalhães et al., 2017; Pillar et al., 2015). These oligomers might have a similar fluorescence peak to those of the humic-like fluorophores, so that the humic-like fluorophores identified herein might also be ascribed to the polyhydroxylated aromatics. These results indicate that humiclike fluorophores or possible polyhydroxylated aromatics in $\mathrm{BB} \mathrm{BrC}$ are gradually enriched during $\mathrm{O}_{3}$ aging. This is in good agreement with the findings from the enhanced humification of $\mathrm{BB} \mathrm{BrC}$ with the increased $\mathrm{HIX}$ values after $\mathrm{O}_{3}$ aging. Importantly, the resulting humic-like fluorophore distribution is similar to the $84 \%-85 \%$ range reported in previous field WSOM measurements (Chen et al., 2016b; Matos et al., 2015), which thus implies that the fluorophore distributions for aged $\mathrm{BB} \mathrm{BrC}$ are similar to relevant atmospheric distributions. In addition, it is obvious that the quenching behavior of each fluorophore is highly different among the three types of $\mathrm{BB} \mathrm{BrC}$ during $\mathrm{O}_{3}$ aging. For example, smaller distributions of HULIS-1 and larger distributions of HULIS-3 in the aged PW smoke $\mathrm{BrC}$ were found relative to those in the aged crop straw smoke BrC (Fig. 4b). This implies that PW $\mathrm{BrC}$ contains less high-molecular-weight HULISs and more low-molecular-weight HULISs with highly oxygenated fluorophores.

\subsection{D-COS combined with fluorescence and FTIR spectra}

Two-dimensional correlation spectroscopy was applied to the series of SF and FTIR spectra to tentatively interpret the $\mathrm{O}_{3}$ aging mechanism of BB BrC. As shown in Fig. S9, the major autopeaks centered at 267/289, 284, and $276 \mathrm{~nm}$ are present in the RS, CS, and PW BrC synchronous maps, respectively. These peaks are all within the protein-like fluorescent region, suggesting that the protein-like substances in the samples are 
(a)

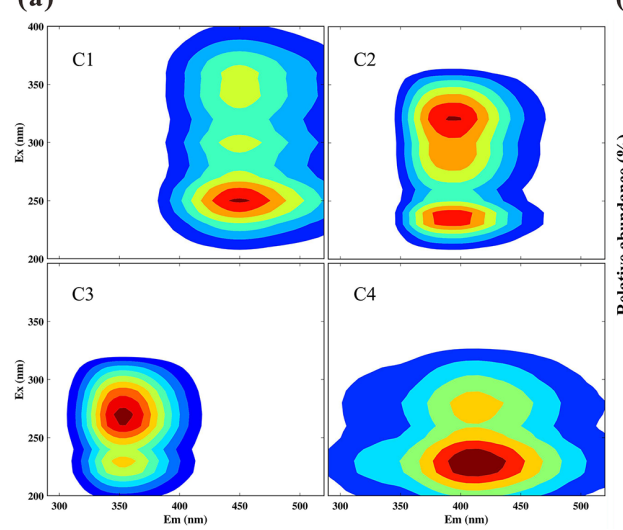

(b)

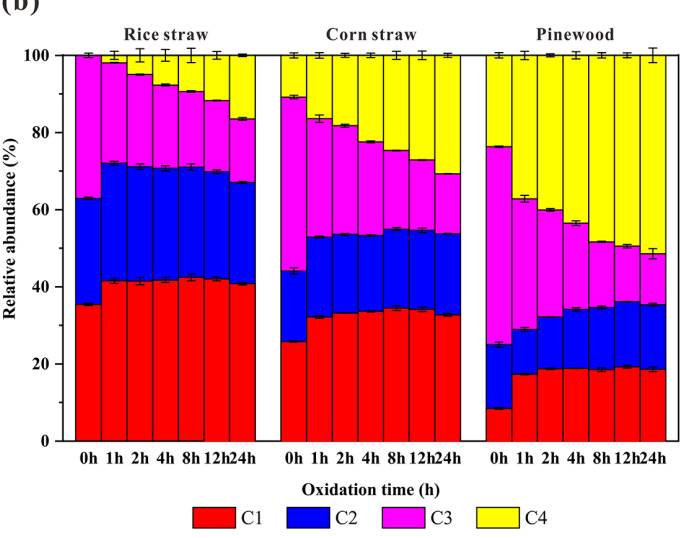

Figure 4. (a) Three fluorescent components of the BB BrC identified by the EEM-PARAFAC model. (b) Variations in the abundances of the individual fluorescent components (C1-C4) within the water-soluble $\mathrm{BrC}$ in $\mathrm{RS}, \mathrm{CS}$, and $\mathrm{PW}$ smoke particles during the ozone aging process. The fluorescent spectra of components $\mathrm{C} 1-\mathrm{C} 4$ are listed in the upper layer, and the corresponding loading positions and identification are shown in Table S1.

very susceptible to $\mathrm{O}_{3}$ aging. These results agree well with the significantly reduced PLOM found from the PARAFACderived fluorophore analysis. The asynchronous maps further revealed the sequential changes of the fluorophores within the BrC, as illustrated in Fig. S10. According to Noda's rule and the signs of the cross peaks given in Table S2, the order of fluorophore changes is as follows: 267,289 , and $333 \mathrm{~nm}$ for the RS BrC; 263, 284, and $340 \mathrm{~nm}$ for the CS $\mathrm{BrC}$; and 309, 276, and $358 \mathrm{~nm}$ for the PW BrC. The fluorescence regions in the wavelength ranges of 250 to $300 \mathrm{~nm}$ and 300 to $380 \mathrm{~nm}$ are usually attributed to protein-like and fulvic-like fluorophores, respectively (Chen et al., 2015; Jin et al., 2018; Pantelaki et al., 2018). It is obvious that the $\mathrm{RS}$ and CS BrC exhibited the same susceptible fluorophore changes upon $\mathrm{O}_{3}$ aging, showing that the oxidation of the protein-like fraction (263-289 nm) occurred earlier than that of the fulvic-like fraction $(333-340 \mathrm{~nm})$. For the $\mathrm{PW} \mathrm{BrC}$, the $\mathrm{O}_{3}$ aging of the fulvic-like fluorophores with shorter wavelengths $(309 \mathrm{~nm})$ took place before the protein-like fluorophores $(276 \mathrm{~nm})$, which was followed by the fulvic-like fluorophores with longer wavelengths $(358 \mathrm{~nm})$. The results also imply that the reaction sites in the $\mathrm{PW} \mathrm{BrC}$ under $\mathrm{O}_{3}$ aging were different from those in crop straw burning $\mathrm{BrC}$. Taken together, it can be concluded that the protein-like substances were susceptible fluorophores, which were primarily oxidized before the longer-wavelength fulvic-like substances. This, however, is in contrast with the results from the dark $\mathrm{OH}$ radical oxidation of $\mathrm{BB} \mathrm{BrC}$ reported in our recent study (Fan et al., 2019), suggesting that the fluorophores within the $\mathrm{BrC}$ oxidized by $\mathrm{OH}$ in the aqueous phase and those by $\mathrm{O}_{3}$ in the particle phase are different.

The main changes in the FTIR spectra of the $\mathrm{BB} \mathrm{BrC}$ upon $\mathrm{O}_{3}$ aging are displayed in the range $1800-1000 \mathrm{~cm}^{-1}$ (Fig. 5). Detailed information regarding any variations in the intensity and sequence of the functional groups upon $\mathrm{O}_{3}$ aging can be revealed with 2D-FTIR-COS (2D-COS combined with FTIR), where synchronous and asynchronous maps were obtained, as shown in Fig. 5. The position and signs of the autopeaks and cross peaks are summarized in Table S3. In general, the synchronous maps exhibit one autopeak at $1725 \mathrm{~cm}^{-1}$ for RS BrC, two autopeaks at 1726 and $1639 \mathrm{~cm}^{-1}$ for $\mathrm{CS} \mathrm{BrC}$, and two autopeaks at 1725 and $1630 \mathrm{~cm}^{-1}$ for $\mathrm{PW} \mathrm{BrC}$. These findings suggest that carboxylic $\mathrm{C}=\mathrm{O}\left(1725,1726 \mathrm{~cm}^{-1}\right)$ and aromatic $\mathrm{C}=\mathrm{C}$ and $\mathrm{C}=\mathrm{O}$ groups $\left(1630,1639 \mathrm{~cm}^{-1}\right.$ ) (Yan et al., 2013; Fan et al., 2016, 2013; Chen et al., 2015; Zhao et al., 2016) are very susceptible to $\mathrm{O}_{3}$ aging. This result can be confirmed by the evolutionary behavior of $\mathrm{O}_{3}$ oxidation of BB-derived phenolic compounds (Pillar et al., 2014, 2015, 2017). For example, $\mathrm{O}_{3}$ primarily attacked the $\mathrm{C}=\mathrm{C}$ bond in such oxy-aromatics to yield polyfunctional low-molecular-weight carboxylic acids containing $\mathrm{C}=\mathrm{O}$ groups (Pillar et al., 2014, 2015, 2017). In addition, the cross peaks generally showed a positive correlation between the series of bands at 1725 (1726), 1639, 1630, 1400, 1318, and $1224(1211) \mathrm{cm}^{-1}$. This implies that the stretching of carboxylic $\mathrm{C}=\mathrm{O}\left(1725,1726 \mathrm{~cm}^{-1}\right)$; phenol$\mathrm{OH}\left(1400,1224,1211 \mathrm{~cm}^{-1}\right)$; and aromatic $\mathrm{C}=\mathrm{C}$, ketone, and amide $\mathrm{C}=\mathrm{O}$ groups $\left(1630,1639 \mathrm{~cm}^{-1}\right)$ (Yan et al., 2013; Fan et al., 2016, 2013; Chen et al., 2015; Zhao et al., 2016; Wang et al., 2017) was cotransformed upon $\mathrm{O}_{3}$ aging. It is also in good agreement with the ozonolysis pathway for BBderived oxy-aromatics (Pillar et al., 2014, 2015, 2017). For example, the $\mathrm{O}_{3}$ oxidation of oxy-aromatics can cause the cleavage of the aromatic bond $(\mathrm{C}=\mathrm{C})$ to generate polyfunctional low-molecular-weight carboxylic acids $(\mathrm{C}=\mathrm{O})$ and also formation of polyhydroxylated aromatics (phenol-OH). Moreover, the cross peaks also presented a positive correlation between another series of bands at 1585 (1580) and $1515 \mathrm{~cm}^{-1}$, suggesting that the vibration of aromatic $\mathrm{COO}^{-}$ $\left(1580,1585 \mathrm{~cm}^{-1}\right)$ and lignin skeletal $\mathrm{C}=\mathrm{C}\left(1515 \mathrm{~cm}^{-1}\right)$ 

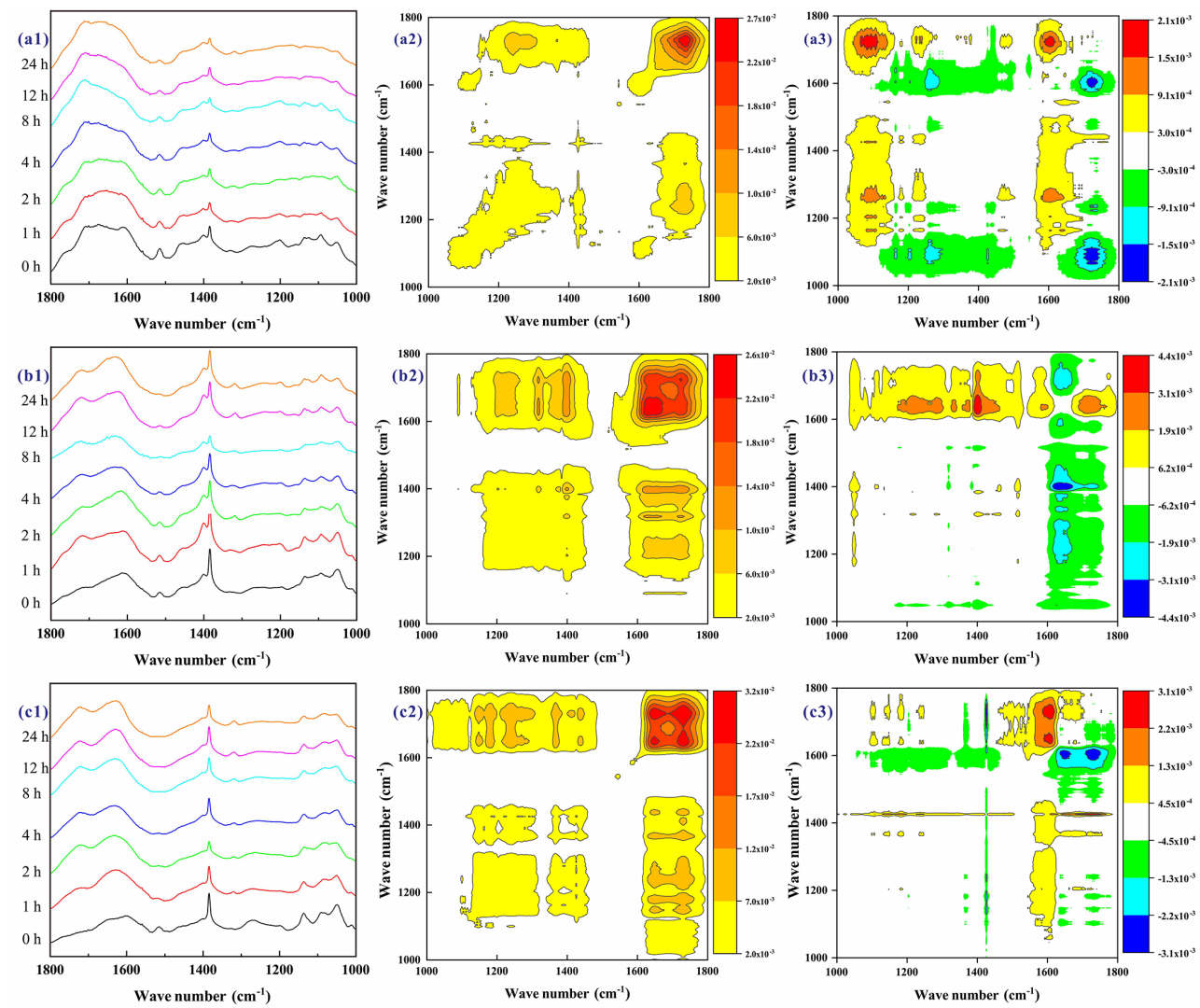

Figure 5. FTIR spectra, and the corresponding synchronous and asynchronous 2D-FTIR-COS maps for the RS (a1-a3), CS (b1-b3), and $\mathrm{PW}$ (c1-c3) BrC during the ozone aging process.

(Fan et al., 2016; Yan et al., 2013; Wang et al., 2017) was also changed in the same way. However, there is a negative correlation between these two series of bands, implying that the spectral changes proceeded in reverse. Given the changes seen in the FTIR spectra (Fig. 5a1-c1), we can conclude that the former groups (i.e., carboxylic $\mathrm{C}=\mathrm{O}$, phenol-OH, protein $\mathrm{C}=\mathrm{C}$ and $\mathrm{C}=\mathrm{O}$, and aromatic ketone $\mathrm{C}=\mathrm{O}$ groups) are more likely to be generated, while the lignin structures (i.e., aromatic $\mathrm{COO}^{-}$and lignin skeletal $\mathrm{C}=\mathrm{C}$ ) tend to be decomposed. Actually, this is consistent with observations of more oxygen-containing functional groups (i.e., ketones, aldehydes, and anhydrides) that formed in soot particles after $\mathrm{O}_{3}$ oxidation reported in many previous studies (He et al., 2017; Li et al., 2013, 2015). For example, He et al. (2017) pointed out that $\mathrm{O}_{3}$-aged soot particles presented an increase in the intensities of the bands at 1715,1630 , and $1055 \mathrm{~cm}^{-1}$ in their FTIR spectra, suggesting the formation of ketone $\mathrm{C}=\mathrm{O}$ and $\mathrm{C}-\mathrm{O}$ groups. The increase in oxygen-containing functional groups might lead to the solubility of OC, which is in good agreement with the former observations of much more WSOC being generated during the $\mathrm{O}_{3}$ aging of $\mathrm{BB}$ smoke particles.

The asynchronous maps displayed more information regarding the changes in the functional groups. The major cross peaks and their signs are listed in Table S3. According to Noda's rule, the sequence of bands upon $\mathrm{O}_{3}$ aging is as follows: $1224,1725,1580$, and $1515 \mathrm{~cm}^{-1}$ for the RS BrC; 1400, 1211, 1726, 1639, and $1515 \mathrm{~cm}^{-1}$ for the CS BrC; and 1630, 1725, 1585, 1515, and $1318 \mathrm{~cm}^{-1}$ for the $\mathrm{PW} \mathrm{BrC}$. These indicate that different functional groups within the $\mathrm{BrC}$ formed or changed during $\mathrm{O}_{3}$ aging. Nevertheless, the similar structural change sequence of the $\mathrm{BB}$ $\mathrm{BrC}$ functional groups upon $\mathrm{O}_{3}$ aging could be ascertained. The changes follow the order of aromatic OH $(1400,1224$, $\left.1211 \mathrm{~cm}^{-1}\right)$; conjugated $\mathrm{C}=\mathrm{O}$ groups $\left(1725,1726 \mathrm{~cm}^{-1}\right)$ and aromatic $\mathrm{C}=\mathrm{O}\left(1630,1639 \mathrm{~cm}^{-1}\right)$; aromatic $\mathrm{COO}^{-}(1585$ and $\left.1580 \mathrm{~cm}^{-1}\right)$; and lignin-derived $\mathrm{C}-\mathrm{C}, \mathrm{C}-\mathrm{H}$, and $\mathrm{C}-\mathrm{O}$ groups $\left(1515\right.$ and $\left.1318 \mathrm{~cm}^{-1}\right)$. Actually, the conjugated $\mathrm{C}=\mathrm{O}$ formation was observed to have occurred before aromatic $\mathrm{C}=\mathrm{O}$ formation for the $\mathrm{CS} \mathrm{BrC}\left(1726>1639 \mathrm{~cm}^{-1}\right)$ during $\mathrm{O}_{3}$ aging, while the reverse sequences were observed for the $\operatorname{PW} \operatorname{BrC}\left(1630>1725 \mathrm{~cm}^{-1}\right)$. These results suggest that the aromatic $\mathrm{C}=\mathrm{O}$ functional groups involved with $\mathrm{O}_{3}$ aging are different for these two types of $\mathrm{BB} \mathrm{BrC}$. As revealed by our previous study, the pyrolysis of CS and PW HULISs dominantly generated lignin derivatives, but amounts of diterpenoid derivatives were also formed by pyrolysis of PW HULISs (Fan et al., 2016). Therefore, it can be speculated 
that the $1639 \mathrm{~cm}^{-1}$ feature can more likely be attributed to the stretching of aromatic $\mathrm{C}=\mathrm{O}$, linked to the lignin derivative of the $\mathrm{CS} \mathrm{BrC}$, while the $1630 \mathrm{~cm}^{-1}$ feature can more likely be ascribed to the stretching of aromatic $\mathrm{C}=\mathrm{C}$ and $\mathrm{C}=\mathrm{O}$, linked to the diterpenoid derivatives of the $\mathrm{PW} \mathrm{BrC}$.

\section{Conclusions and atmospheric implications}

In this study, the $\mathrm{O}_{3}$ aging of $\mathrm{BB}$ smoke particles from the burning of RS, CS, and PW was conducted to investigate the evolutionary behavior of $\mathrm{BrC}$. The results showed that the WSOC content of $\mathrm{BB} \mathrm{BrC}$ quickly increased during the initial $\mathrm{O}_{3}$ aging period but slowly decreased during the final $\mathrm{O}_{3}$ aging period. Simultaneously, the $\mathrm{O}_{3}$ aging led to a gradual reduction of absorption and fluorescence for all the $\mathrm{BB} \mathrm{BrC}$ samples, suggesting the significant degradation of chromophores and fluorophores. Moreover, a decrease in aromaticity and light-absorbing ability of the chromophores and an increase in humification of the fluorophores within the $\mathrm{BB} \mathrm{BrC}$ were also observed during the aging process. Therefore, it might be concluded that both the degradation and formation of water-soluble $\mathrm{OC}$ fractions occur during $\mathrm{O}_{3}$ aging.

EEM-PARAFAC revealed that HULIS-1, HULIS-2, and PLOM within the BB samples were significantly degraded, but newly formed HULIS-3 was obviously observed for two of the RS and CS samples. In addition, the relative distribution of PLOM gradually decreased, and that of HULIS-3 was observed to gradually increase for all the $\mathrm{BB} \mathrm{BrC}$ samples. This indicates that the aged $\mathrm{BB} \mathrm{BrC}$ contains more humiclike substances with highly oxygenated chromophores but fewer protein-like substances. These results also confirm that the fluorophore composition of $\mathrm{BrC}$ is altered by the $\mathrm{O}_{3}$ aging of the $\mathrm{BB}$ particles, and more humic-like substances (HULIS-1, 2, 3) are abundant in aged BB BrC. It is noted that the fluorescent components of the aged $\mathrm{BB} \mathrm{BrC}$ are quite similar to those of atmospheric $\mathrm{BrC}$.

Two-dimensional correlation spectroscopy of the SF and FTIR spectra revealed valuable information regarding the reactive positions and sequences within $\mathrm{BB} \mathrm{BrC}$ for $\mathrm{O}_{3}$ aging. Although the different chemical compositions of $\mathrm{BB}$ $\mathrm{BrC}$ resulted in different evolutionary behavior, some similar $\mathrm{O}_{3}$ aging mechanisms could be tentatively identified. The results from 2D-SF-COS analysis suggest that the proteinlike fraction $(263-289 \mathrm{~nm})$ is susceptible to $\mathrm{O}_{3}$ aging before the fulvic-like fraction $(333-340 \mathrm{~nm})$ within the RS and CS BrC. The PW BrC presented susceptible fluorophores in the order of fulvic-like fluorophores with shorter wavelengths $(309 \mathrm{~nm})$, protein-like fluorophores $(276 \mathrm{~nm})$, and fulvic-like fluorophores with longer wavelengths $(358 \mathrm{~nm})$. The 2D-FTIR-COS analysis revealed the sequence of aromatic $\mathrm{OH}\left(1400,1224,1211 \mathrm{~cm}^{-1}\right)$; conjugated $\mathrm{C}=\mathrm{O}$ groups $\left(1725 \mathrm{~cm}^{-1}\right)$ and aromatic $\mathrm{C}=\mathrm{O}\left(1630,1639 \mathrm{~cm}^{-1}\right)$; aromatic $\mathrm{COO}^{-}\left(1585\right.$ and $\left.1580 \mathrm{~cm}^{-1}\right)$; and lignin-derived $\mathrm{C}-$ $\mathrm{C}, \mathrm{C}-\mathrm{H}$, and $\mathrm{C}-\mathrm{O}$ groups $\left(1515\right.$ and $\left.1318 \mathrm{~cm}^{-1}\right)$ for all the
BB BrC. This implies that the formation of phenols occurred before the formation of carboxylic $\mathrm{C}=\mathrm{O}$ and aromatic $\mathrm{C}=\mathrm{O}$ through $\mathrm{O}$ addition, which were then accompanied by the decomposition of lignin derivatives for all the $\mathrm{BB} \mathrm{BrC}$ during $\mathrm{O}_{3}$ aging.

Given the high concentrations of $\mathrm{O}_{3}$ and large amounts of $\mathrm{BB}$ emission in the atmosphere, $\mathrm{O}_{3}$ aging processes often occur in the atmospheric environment. The results obtained in this study provide new insights into the evolutionary behavior of the chromophoric and fluorescent properties of $\mathrm{BB} \mathrm{BrC}$ during $\mathrm{O}_{3}$ aging, which have important implications in terms of the heterogeneous oxidation of $\mathrm{BB} \mathrm{BrC}$. Furthermore, previous modeling studies related to $\mathrm{BB} \mathrm{BrC}$ only focused on parameterizing the optical properties of fresh $\mathrm{BB} \mathrm{BrC}$, and the consideration of effects related to atmospheric processes on $\mathrm{BB} \mathrm{BrC}$ is limited. The present study revealed that a considerable bleaching rather than competitive formation of chromophoric $\mathrm{BrC}$ occurred during $\mathrm{O}_{3}$ aging of $\mathrm{BB}$ smoke samples, indicating that the relevant oxidation chemistry taking place in the atmospheric gas phase will weaken the light absorption properties of BB-derived $\mathrm{BrC}$. As a result, the radiative forcing potential of BB-derived $\mathrm{BrC}$ is likely overestimated. These findings are of great importance for improving the accuracy of climate models as well as source apportionment models that consider the optical properties of $\mathrm{BrC}$. However, some questions still remain and more studies should be conducted in the future on (1) the $\mathrm{O}_{3}$ oxidation mechanism of $\mathrm{BB} \mathrm{BrC}$ under different conditions (e.g., $\mathrm{O}_{3}$ concentration, $\mathrm{RH}$, temperature), especially under real atmospheric environment, and (2) the $\mathrm{O}_{3}$ oxidation mechanism of $\mathrm{BrC}$ derived from other sources such as fossil fuel combustion and secondary chemical formation.

Data availability. All data needed to evaluate the conclusions in the paper are present in the paper and Supplement. Additional data related to this paper may be requested from the authors.

Supplement. The supplement related to this article is available online at: https://doi.org/10.5194/acp-20-4593-2020-supplement.

Author contributions. JS, PP, and XF conceived of the experiment. TC and XY built the ozone aging reactor and operated the ozone aging of biomass burning fine particles. TC, XY, YW, and WJ performed the TOC, UV-Vis, 3DEEM, and FTIR measurements. XF and JS performed 2D-COS and PARAFAC. XF interpreted all data with the assistance of JS. XX, FL, YW, and YX provided useful comments on the paper. XF wrote the paper with the assistance of JS and PP.

Competing interests. The authors declare that they have no conflict of interest. 
Special issue statement. This article is part of the special issue "Multiphase chemistry of secondary aerosol formation under severe haze". It is not associated with a conference.

Acknowledgements. The authors acknowledge the editor and anonymous reviewers for their constructive suggestions.

Financial support. This research has been supported by the Natural Science Foundation of China (grant nos. 41705107 and 41673117), the Anhui Science and Technology Major Project (grant no. 16030701102), and the Anhui Provincial Natural Science Foundation (grant no. 1808085MB49).

Review statement. This paper was edited by Jian Wang and reviewed by two anonymous referees.

\section{References}

Andreae, M. O. and Gelencsér, A.: Black carbon or brown carbon? The nature of light-absorbing carbonaceous aerosols, Atmos. Chem. Phys., 6, 3131-3148, https://doi.org/10.5194/acp-63131-2006, 2006.

Arhami, M., Kuhn, T., Fine, P. M., Delfino, R. J., and Sioutas, C.: Effects of Sampling Artifacts and Operating Parameters on the Performance of a Semicontinuous Particulate Elemental Carbon/Organic Carbon Monitor, Environ. Sci. Technol., 40, 945954, https://doi.org/10.1021/es0510313, 2006.

Baduel, C., Monge, M. E., Voisin, D., Jaffrezo, J. L., George, C., Haddad, I. E., Marchand, N., and D'Anna, B.: Oxidation of atmospheric humic like substances by ozone: a kinetic and structural analysis approach, Environ. Sci. Technol., 45, 5238-5244, https://doi.org/10.1021/es200587z, 2011.

Bond, T. C.: A technology-based global inventory of black and organic carbon emissions from combustion, J. Geophys. Res., 109, D14203, https://doi.org/10.1029/2003jd003697, 2004.

Chang, J. L. and Thompson, J. E.: Characterization of colored products formed during irradiation of aqueous solutions containing $\mathrm{H}_{2} \mathrm{O}_{2}$ and phenolic compounds, Atmos. Environ., 44, 541-551, https://doi.org/10.1016/j.atmosenv.2009.10.042, 2010.

Chapleski, R. C., Zhang, Y., Troya, D., and Morris, J. R.: Heterogeneous chemistry and reaction dynamics of the atmospheric oxidants, $\mathrm{O}_{3}, \mathrm{NO}_{3}$, and $\mathrm{OH}$, on organic surfaces, Chem. Soc. Rev., 45, 3731-3746, https://doi.org/10.1039/C5CS00375J, 2016.

Chen, Q., Ikemori, F., and Mochida, M.: Light Absorption and Excitation-Emission Fluorescence of Urban Organic Aerosol Components and Their Relationship to Chemical Structure, Environ. Sci. Technol., 50, 10859-10868, https://doi.org/10.1021/acs.est.6b02541, 2016a.

Chen, Q., Miyazaki, Y., Kawamura, K., Matsumoto, K., Coburn, S., Volkamer, R., Iwamoto, Y., Kagami, S., Deng, Y., Ogawa, S., Ramasamy, S., Kato, S., Ida, A., Kajii, Y., and Mochida, M.: Characterization of Chromophoric WaterSoluble Organic Matter in Urban, Forest, and Marine Aerosols by HR-ToF-AMS Analysis and Excitation-Emission Ma- trix Spectroscopy, Environ. Sci. Technol., 50, 10351-10360, https://doi.org/10.1021/acs.est.6b01643, 2016b.

Chen, Q., Wang, M., Wang, Y., Zhang, L., Li, Y., and Han, Y: Oxidative Potential of Water-Soluble Matter Associated with Chromophoric Substances in $\mathrm{PM}_{2.5}$ over Xi'an, China, Environ. Sci. Technol., 53, 8574-8584, https://doi.org/10.1021/acs.est.9b01976, 2019.

Chen, W., Habibul, N., Liu, X. Y., Sheng, G. P., and Yu, H. Q.: FTIR and synchronous fluorescence heterospectral two-dimensional correlation analyses on the binding characteristics of copper onto dissolved organic matter, Environ. Sci. Technol., 49, 2052-2058, https://doi.org/10.1021/es5049495, 2015.

Chen, Y. and Bond, T. C.: Light absorption by organic carbon from wood combustion, Atmos. Chem. Phys., 10, 1773-1787, https://doi.org/10.5194/acp-10-1773-2010, 2010.

Chen, Y., Ge, X., Chen, H., Xie, X., Chen, Y., Wang, J., Ye, Z., Bao, M., Zhang, Y., and Chen, M.: Seasonal light absorption properties of water-soluble brown carbon in atmospheric fine particles in Nanjing, China, Atmos. Environ., 187, 230-240, https://doi.org/10.1016/j.atmosenv.2018.06.002, 2018.

Cheng, Y., He, K.-B., Du, Z.-Y., Engling, G., Liu, J.-M., Ma, Y.-L., Zheng, M., and Weber, R. J.: The characteristics of brown carbon aerosol during winter in Beijing, Atmos. Environ., 127, 355-364, https://doi.org/10.1016/j.atmosenv.2015.12.035, 2016.

Chi, X., Liu, C., Xie, Z., Fan, G., Wang, Y., He, P., Fan, S., Hong, Q., Wang, Z., Yu, X., Yue, F., Duan, J., Zhang, P., and Liu, J.: Observations of ozone vertical profiles and corresponding precursors in the low troposphere in Beijing, China, Atmos. Res., 213, 224235, https://doi.org/10.1016/j.atmosres.2018.06.012, 2018.

Chung, C. E., Ramanathan, V., and Decremer, D.: Observationally constrained estimates of carbonaceous aerosol radiative forcing, P. Natl. Acad. Sci. USA, 109, 11624-11629, https://doi.org/10.1073/pnas.1203707109, 2012.

D’Anna, B., Jammoul, A., George, C., Stemmler, K., Fahrni, S., Ammann, M., and Wisthaler, A.: Light-induced ozone depletion by humic acid films and submicron aerosol particles, J. Geophys. Res., 114, D12301, https://doi.org/10.1029/2008jd011237, 2009.

Decesari, S., Facchini, M. C., Matta, E., Mircea, M., Fuzzi, S., Chughtai, A. R., and Smith, D. M.: Water soluble organic compounds formed by oxidation of soot, Atmos. Environ., 36, 18271832, 2002.

De Haan, D. O., Hawkins, L. N., Welsh, H. G., Pednekar, R., Casar, J. R., Pennington, E. A., De, L. A., Jimenez, N. G., Symons, M. A., and Zauscher, M. D.: Brown carbon production in ammonium- or amine-containing aerosol particles by reactive uptake of methylglyoxal and photolytic cloud cycling, Environ. Sci. Technol., 51, 7458-7466, 2017.

Duarte, R. M. B. O., Freire, S. M. S. C., and Duarte, A. C.: Investigating the water-soluble organic functionality of urban aerosols using two-dimensional correlation of solid-state $13 \mathrm{C}$ NMR and FTIR spectral data, Atmos. Environ., 116, 245-252, https://doi.org/10.1016/j.atmosenv.2015.06.043, 2015.

Eugene, A. J., Xia, S.-S., and Guzman, M. I.: Aqueous Photochemistry of Glyoxylic Acid, The J. Phys. Chem. A, 120, 3817-3826, https://doi.org/10.1021/acs.jpca.6b00225, 2016.

Fan, X., Song, J., and Peng, P.: Comparative study for separation of atmospheric humic-like substance (HULIS) by ENVI18, HLB, XAD-8 and DEAE sorbents: elemental composition, FT-IR, 1H NMR and off-line thermochemolysis with tetramethy- 
lammonium hydroxide (TMAH), Chemosphere, 93, 1710-1719, https://doi.org/10.1016/j.chemosphere.2013.05.045, 2013.

Fan, X., Wei, S., Zhu, M., Song, J., and Peng, P.: Comprehensive characterization of humic-like substances in smoke $\mathrm{PM}_{2.5}$ emitted from the combustion of biomass materials and fossil fuels, Atmos. Chem. Phys., 16, 13321-13340, https://doi.org/10.5194/acp-16-13321-2016, 2016.

Fan, X., Li, M., Cao, T., Cheng, C., Li, F., Xie, Y., Wei, S., Song, J., and Peng, P. A.: Optical properties and oxidative potential of water- and alkaline-soluble brown carbon in smoke particles emitted from laboratory simulated biomass burning, Atmos. Environ., 194, 48-57, https://doi.org/10.1016/j.atmosenv.2018.09.025, 2018.

Fan, X., Yu, X., Wang, Y., Xiao, X., Li, F., Xie, Y., Wei, S., Song, J., and Peng, P. A.: The aging behaviors of chromophoric biomass burning brown carbon during dark aqueous hydroxyl radical oxidation processes in laboratory studies, Atmos. Environ., 205, 918, https://doi.org/10.1016/j.atmosenv.2019.02.039, 2019.

Feng, Y., Ramanathan, V., and Kotamarthi, V. R.: Brown carbon: a significant atmospheric absorber of solar radiation?, Atmos. Chem. Phys., 13, 8607-8621, https://doi.org/10.5194/acp13-8607-2013, 2013.

Gallimore, P. J., Achakulwisut, P., Pope, F. D., Davies, J. F., Spring, D. R., and Kalberer, M.: Importance of relative humidity in the oxidative ageing of organic aerosols: case study of the ozonolysis of maleic acid aerosol, Atmos. Chem. Phys., 11, 12181-12195, https://doi.org/10.5194/acp-11-12181-2011, 2011.

Gao, J., Liang, C., Shen, G., Lv, J., and Wu, H.: Spectral characteristics of dissolved organic matter in various agricultural soils throughout China, Chemosphere, 176, 108-116, https://doi.org/10.1016/j.chemosphere.2017.02.104, 2017.

Geller, M. D., Ntziachristos, L., Mamakos, A., Samaras, Z., Schmitz, D. A., Froines, J. R., and Sioutas, C.: Physicochemical and redox characteristics of particulate matter $(\mathrm{PM})$ emitted from gasoline and diesel passenger cars, Atmos. Environ., 40, 69887004, https://doi.org/10.1016/j.atmosenv.2006.06.018, 2006.

He, X., Pang, S., Ma, J., and Zhang, Y.: Influence of relative humidity on heterogeneous reactions of $\mathrm{O}_{3}$ and $\mathrm{O}_{3} / \mathrm{SO}_{2}$ with soot particles: Potential for environmental and health effects, Atmos. Environ., 165, 198-206, https://doi.org/10.1016/j.atmosenv.2017.06.049, 2017.

Hecobian, A., Zhang, X., Zheng, M., Frank, N., Edgerton, E. S., and Weber, R. J.: Water-Soluble Organic Aerosol material and the light-absorption characteristics of aqueous extracts measured over the Southeastern United States, Atmos. Chem. Phys., 10, 5965-5977, https://doi.org/10.5194/acp-10-5965-2010, 2010.

Hems, R. F. and Abbatt, J. P. D.: Aqueous Phase Photo-oxidation of Brown Carbon Nitrophenols: Reaction Kinetics, Mechanism, and Evolution of Light Absorption, ACS Earth Space Chem., 2, 225-234, https://doi.org/10.1021/acsearthspacechem.7b00123, 2018.

Holmes, B. J. and Petrucci, G. A.: Water-Soluble Oligomer Formation from Acid-Catalyzed Reactions of Levoglucosan in Proxies of Atmospheric Aqueous Aerosols, Environ. Sci. Technol., 40, 4983-4989, https://doi.org/10.1021/es060646c, 2006.

Huang, M., Li, Z., Huang, B., Luo, N., Zhang, Q., Zhai, X., and Zeng, G.: Investigating binding characteristics of cadmium and copper to DOM derived from compost and rice straw using EEM-PARAFAC combined with two-dimensional
FTIR correlation analyses, J. Hazard Mater., 344, 539-548, https://doi.org/10.1016/j.jhazmat.2017.10.022, 2018.

Huo, Y., Li, M., Jiang, M., and Qi, W.: Light absorption properties of HULIS in primary particulate matter produced by crop straw combustion under different moisture contents and stacking modes, Atmos. Environ., 191, 490-499, https://doi.org/10.1016/j.atmosenv.2018.08.038, 2018.

Hur, J. and Lee, B.-M.: Characterization of copper binding properties of extracellular polymeric substances using a fluorescence quenching approach combining twodimensional correlation spectroscopy, J. Mol. Struct., 1069, 7984, https://doi.org/10.1016/j.molstruc.2013.11.056, 2014.

Jamieson, T., Sager, E., and Guéguen, C.: Characterization of biochar-derived dissolved organic matter using UV-visible absorption and excitation-emission fluorescence spectroscopies, Chemosphere, 103, 197-204, https://doi.org/10.1016/j.chemosphere.2013.11.066, 2014.

Jin, P., Song, J., Wang, X. C., and Jin, X.: Two-dimensional correlation spectroscopic analysis on the interaction between humic acids and aluminum coagulant, J. Environ. Sci., 64, 181-189, https://doi.org/10.1016/j.jes.2017.06.018, 2018.

Jo, D. S., Park, R. J., Lee, S., Kim, S.-W., and Zhang, X.: A global simulation of brown carbon: implications for photochemistry and direct radiative effect, Atmos. Chem. Phys., 16, 3413-3432, https://doi.org/10.5194/acp-16-3413-2016, 2016.

Kumar, N. K., Corbin, J. C., Bruns, E. A., Massabó, D., Slowik, J. G., Drinovec, L., Močnik, G., Prati, P., Vlachou, A., Baltensperger, U., Gysel, M., El-Haddad, I., and Prévôt, A. S. H.: Production of particulate brown carbon during atmospheric aging of residential wood-burning emissions, Atmos. Chem. Phys., 18, 17843-17861, https://doi.org/10.5194/acp-18-178432018, 2018.

Laskin, A., Laskin, J., and Nizkorodov, S. A.: Chemistry of Atmospheric Brown Carbon, Chem. Rev., 115, 4335-4382, https://doi.org/10.1021/cr5006167, 2015.

Lavi, A., Lin, P., Bhaduri, B., Carmieli, R., Laskin, A., and Rudich, Y.: Characterization of Light-Absorbing Oligomers from Reactions of Phenolic Compounds and Fe(III), ACS Earth Space Chem., 1, 637-646, https://doi.org/10.1021/acsearthspacechem.7b00099, 2017.

Lawaetz, A. J. and Stedmon, C. A.: Fluorescence intensity calibration using the Raman scatter peak of water, Appl Spectrosc., 63, 936-940, https://doi.org/10.1366/000370209788964548, 2009.

Lee, A. K. Y. and Chan, C. K.: Heterogeneous Reactions of Linoleic Acid and Linolenic Acid Particles with Ozone: Reaction Pathways and Changes in Particle Mass, Hygroscopicity, and Morphology, The J. Phys. Chem. A, 111, 6285-6295, https://doi.org/10.1021/jp0718121, 2007.

Li, J., Chen, X., Wang, Z., Du, H., Yang, W., Sun, Y., Hu, B., Li, J., Wang, W., Wang, T., Fu, P., and Huang, H.: Radiative and heterogeneous chemical effects of aerosols on ozone and inorganic aerosols over East Asia, Sci. Total Environ., 622-623, 13271342, https://doi.org/10.1016/j.scitotenv.2017.12.041, 2018.

Li, K., Chen, L., Han, K., Lv, B., Bao, K., Wu, X., Gao, X., and Cen, K.: Smog chamber study on aging of combustion soot in isoprene/ $\mathrm{SO}_{2} / \mathrm{NO}_{\mathrm{x}}$ system: Changes of mass, size, effective density, morphology and mixing state, Atmos. Res., 184, 139-148, https://doi.org/10.1016/j.atmosres.2016.10.011, 2017. 
Li, Q., Shang, J., and Zhu, T.: Physicochemical characteristics and toxic effects of ozone-oxidized black carbon particles, Atmos. Environ., 81, 68-75, https://doi.org/10.1016/j.atmosenv.2013.08.043, 2013.

Li, Q., Shang, J., Liu, J., Xu, W., Feng, X., Li, R., and Zhu, T.: Physicochemical characteristics, oxidative capacities and cytotoxicities of sulfate-coated, 1,4-NQ-coated and ozoneaged black carbon particles, Atmos. Res., 153, 535-542, https://doi.org/10.1016/j.atmosres.2014.10.005, 2015.

Lin, P., Liu, J., Shilling, J. E., Kathmann, S. M., Laskin, J., and Laskin, A.: Molecular characterization of brown carbon $(\mathrm{BrC})$ chromophores in secondary organic aerosol generated from photo-oxidation of toluene, Phys. Chem. Chem. Phys., 17, 23312-23325, https://doi.org/10.1039/C5CP02563J, 2015.

Liu, J., Scheuer, E., Dibb, J., Diskin, G. S., Ziemba, L. D., Thornhill, K. L., Anderson, B. E., Wisthaler, A., Mikoviny, T., Devi, J. J., Bergin, M., Perring, A. E., Markovic, M. Z., Schwarz, J. P., Campuzano-Jost, P., Day, D. A., Jimenez, J. L., and Weber, R. J.: Brown carbon aerosol in the North American continental troposphere: sources, abundance, and radiative forcing, Atmos. Chem. Phys., 15, 7841-7858, https://doi.org/10.5194/acp15-7841-2015, 2015.

Ma, Y., Cheng, Y., Qiu, X., Cao, G., Fang, Y., Wang, J., Zhu, T., $\mathrm{Yu}$, J., and $\mathrm{Hu}, \mathrm{D}$. : Sources and oxidative potential of watersoluble humic-like substances (HULISWS) in fine particulate matter $\left(\mathrm{PM}_{2.5}\right)$ in Beijing, Atmos. Chem. Phys., 18, 5607-5617, https://doi.org/10.5194/acp-18-5607-2018, 2018.

Magalhães, A. C. O., Esteves da Silva, J. C. G., and Pinto da Silva, L.: Density Functional Theory Calculation of the Absorption Properties of Brown Carbon Chromophores Generated by Catechol Heterogeneous Ozonolysis, ACS Earth Space Chem., 1, 353-360, https://doi.org/10.1021/acsearthspacechem.7b00061, 2017.

Matos, J. T. V., Freire, S. M. S. C., Duarte, R. M. B. O., and Duarte, A. C.: Natural organic matter in urban aerosols: Comparison between water and alkaline soluble components using excitation-emission matrix fluorescence spectroscopy and multiway data analysis, Atmos. Environ., 102, 1-10, https://doi.org/10.1016/j.atmosenv.2014.11.042, 2015.

Mok, J., Krotkov, N. A., Arola, A., Torres, O., Jethva, H., Andrade, M., Labow, G., Eck, T. F., Li, Z., and Dickerson, R. R.: Impacts of brown carbon from biomass burning on surface UV and ozone photochemistry in the Amazon Basin, Sci. Rep., 6, 36940, https://doi.org/10.1038/srep36940, 2016.

Pantelaki, I., Papatzelou, A., Balla, D., Papageorgiou, A., and Voutsa, D.: Characterization of dissolved organic carbon in rainwater of an urban/coastal site in Mediterranean area, Sci. Total Environ., 627, 1433-1441, https://doi.org/10.1016/j.scitotenv.2018.01.339, 2018.

Park, S. S. and Yu, J.: Chemical and light absorption properties of humic-like substances from biomass burning emissions under controlled combustion experiments, Atmos. Environ., 136, 114 122, https://doi.org/10.1016/j.atmosenv.2016.04.022, 2016.

Parshintsev, J., Ruiz-Jimenez, J., Petäjä, T., Hartonen, K., Kulmala, M., and Riekkola, M.-L.: Comparison of quartz and Teflon filters for simultaneous collection of size-separated ultrafine aerosol particles and gas-phase zero samples, Anal. Bioanal. Chem., 400, 3527-3535, https://doi.org/10.1007/s00216-011-5041-0, 2011.
Pillar, E. A. and Guzman, M. I.: Oxidation of Substituted Catechols at the Air-Water Interface: Production of Carboxylic Acids, Quinones, and Polyphenols, Environ. Sci. Technol., 5, 49514959, https://doi.org/10.1021/acs.est.7b00232, 2017.

Pillar, E. A., Camm, R. C., and Guzman, M. I.: Catechol Oxidation by Ozone and Hydroxyl Radicals at the AirWater Interface, Environ. Sci. Technol., 48, 14352-14360, https://doi.org/10.1021/es504094x, 2014.

Pillar, E. A., Zhou, R., and Guzman, M. I.: Heterogeneous Oxidation of Catechol, The J. Phys. Chem. A, 119, 10349-10359, https://doi.org/10.1021/acs.jpca.5b07914, 2015.

Pillar-Little, E. and Guzman, M.: An Overview of Dynamic Heterogeneous Oxidations in the Troposphere, Environments, 5, 104, https://doi.org/10.3390/environments5090104, 2018.

Qin, J., Zhang, L., Zhou, X., Duan, J., Mu, S., Xiao, K., Hu, J., and Tan, J.: Fluorescence fingerprinting properties for exploring water-soluble organic compounds in $\mathrm{PM}_{2.5}$ in an industrial city of northwest China, Atmos. Environ., 184, 203-211, https://doi.org/10.1016/j.atmosenv.2018.04.049, 2018.

Rincón, A. G., Guzmán, M. I., Hoffmann, M. R., and Colussi, A. J.: Optical Absorptivity versus Molecular Composition of Model Organic Aerosol Matter, The J. Phys. Chem. A, 113, 10512 10520, https://doi.org/10.1021/jp904644n, 2009.

Rincón, A. G., Guzmán, M. I., Hoffmann, M. R., and Colussi, A. J.: Thermochromism of Model Organic Aerosol Matter, The J. Phys. Chem. Lett., 1, 368-373, https://doi.org/10.1021/jz900186e, 2010.

Saleh, R., Hennigan, C. J., McMeeking, G. R., Chuang, W. K., Robinson, E. S., Coe, H., Donahue, N. M., and Robinson, A. L.: Absorptivity of brown carbon in fresh and photo-chemically aged biomass-burning emissions, Atmos. Chem. Phys., 13, 76837693, https://doi.org/10.5194/acp-13-7683-2013, 2013.

Santos, G. T., Santos, P. S., and Duarte, A. C.: Vanillic and syringic acids from biomass burning: Behaviour during Fenton-like oxidation in atmospheric aqueous phase and in the absence of light, J. Hazard Mater., 313, 201-208, https://doi.org/10.1016/j.jhazmat.2016.04.006, 2016.

Santos, P. S. and Duarte, A. C.: Fenton-like oxidation of small aromatic acids from biomass burning in water and in the absence of light: implications for atmospheric chemistry, Chemosphere, 119, 786-793, https://doi.org/10.1016/j.chemosphere.2014.08.024, 2015.

Santos, P. S., Domingues, M. R., and Duarte, A. C.: Fenton-like oxidation of small aromatic acids from biomass burning in atmospheric water and in the absence of light: Identification of intermediates and reaction pathways, Chemosphere, 154, 599-603, https://doi.org/10.1016/j.chemosphere.2016.04.015, 2016.

Santos, P. S. M., Otero, M., Duarte, R. M. B. O., and Duarte, A. C.: Spectroscopic characterization of dissolved organic matter isolated from rainwater, Chemosphere, 74, 1053-1061, https://doi.org/10.1016/j.chemosphere.2008.10.061, 2009.

Santos, P. S. M., Santos, E. B. H., and Duarte, A. C.: First spectroscopic study on the structural features of dissolved organic matter isolated from rainwater in different seasons, Sci. Total Environ. 426, 172-179, https://doi.org/10.1016/j.scitotenv.2012.03.023, 2012.

Schnitzler, E. G. and Abbatt, J. P. D.: Heterogeneous OH oxidation of secondary brown carbon aerosol, Atmos. Chem. Phys., 
18, 14539-14553, https://doi.org/10.5194/acp-18-14539-2018, 2018.

Stedmon, C. A. and Bro, R.: Characterizing dissolved organic matter fluorescence with parallel factor analysis: a tutorial, Limnol. Oceanogr. Method., 6, 572-579, 2008.

Subramanian, R., Khlystov, A. Y., Cabada, J. C., and Robinson, A. L.: Positive and Negative Artifacts in Particulate Organic Carbon Measurements with Denuded and Undenuded Sampler Configurations Special Issue of Aerosol Science and Technology on Findings from the Fine Particulate Matter Supersites Program, Aerosol Sci. Technol., 38, (sup1), 27-48, https://doi.org/10.1080/02786820390229354, 2004.

Sumlin, B. J., Pandey, A., Walker, M. J., Pattison, R. S., Williams, B. J., and Chakrabarty, R. K.: Atmospheric Photooxidation Diminishes Light Absorption by Primary Brown Carbon Aerosol from Biomass Burning, Environ. Sci. Technol. Lett., 4, 540-545, https://doi.org/10.1021/acs.estlett.7b00393, 2017.

Sun, J., Wei, B., Mei, Q., An, Z., Wang, X., and He, M.: Ozonation of 3-methylcatechol and 4-methylcatechol in the atmosphere and aqueous particles: Mechanism, kinetics and ecotoxicity assessment, Chem. Eng. J., 358, 456-466, https://doi.org/10.1016/j.cej.2018.10.074, 2019.

Tang, M., Alexander, J. M., Kwon, D., Estillore, A. D., Laskina, O., Young, M. A., Kleiber, P. D., and Grassian, V. H.: Optical and Physicochemical Properties of Brown Carbon Aerosol: Light Scattering, FTIR Extinction Spectroscopy, and Hygroscopic Growth, J. Phys. Chem. A, 120, 4155-4166, https://doi.org/10.1021/acs.jpca.6b03425, 2016.

Wang, J., Nie, W., Cheng, Y., Shen, Y., Chi, X., Wang, J., Huang, X., Xie, Y., Sun, P., Xu, Z., Qi, X., Su, H., and Ding, A.: Light absorption of brown carbon in eastern China based on 3-year multiwavelength aerosol optical property observations and an improved absorption Ångström exponent segregation method, Atmos. Chem. Phys., 18, 9061-9074, https://doi.org/10.5194/acp18-9061-2018, 2018.

Wang, Y., Zhang, X., Zhang, X., Meng, Q., Gao, F., and Zhang, Y.: Characterization of spectral responses of dissolved organic matter (DOM) for atrazine binding during the sorption process onto black soil, Chemosphere, 180, 531-539, https://doi.org/10.1016/j.chemosphere.2017.04.063, 2017.
Wong, J. P. S., Nenes, A., and Weber, R. J.: Changes in Light Absorptivity of Molecular Weight Separated Brown Carbon Due to Photolytic Aging, Environ. Sci. Technol., 51, 8414-8421, https://doi.org/10.1021/acs.est.7b01739, 2017.

Wong, J. P. S., Tsagkaraki, M., Tsiodra, I., Mihalopoulos, N., Violaki, K., Kanakidou, M., Sciare, J., Nenes, A., and Weber, R. J.: Atmospheric evolution of molecular-weight-separated brown carbon from biomass burning, Atmos. Chem. Phys., 19, 73197334, https://doi.org/10.5194/acp-19-7319-2019, 2019.

Xia, S.-S., Eugene, A. J., and Guzman, M. I.: Cross Photoreaction of Glyoxylic and Pyruvic Acids in Model Aqueous Aerosol, The J. Phys. Chem. A, 122, 6457-6466, https://doi.org/10.1021/acs.jpca.8b05724, 2018.

Yan, J., Wang, X., Gong, P., Wang, C., and Cong, Z.: Review of brown carbon aerosols: Recent progress and perspectives, Sci. Total Environ., 634, 1475-1485, https://doi.org/10.1016/j.scitotenv.2018.04.083, 2018.

Yan, W., Zhang, J., and Jing, C.: Adsorption of Enrofloxacin on montmorillonite: Two-dimensional correlation ATR/FTIR spectroscopy study, J. Coll. Interf. Sci., 390, 196-203, https://doi.org/10.1016/j.jcis.2012.09.039, 2013.

Zhang, Y., Gao, G., Shi, K., Niu, C., Zhou, Y., Qin, B., and Liu, X.: Absorption and fluorescence characteristics of rainwater CDOM and contribution to Lake Taihu, China, Atmos. Environ., 98, 483-491, https://doi.org/10.1016/j.atmosenv.2014.09.038, 2014.

Zhao, R., Lee, A. K. Y., Huang, L., Li, X., Yang, F., and Abbatt, J. P. D.: Photochemical processing of aqueous atmospheric brown carbon, Atmos. Chem. Phys., 15, 6087-6100, https://doi.org/10.5194/acp-15-6087-2015, 2015.

Zhao, Y., Ma, Q., Liu, Y., and He, H.: Influence of sulfur in fuel on the properties of diffusion flame soot, Atmos. Environ., 142, 383-392, https://doi.org/10.1016/j.atmosenv.2016.08.001, 2016.

Zhong, M. and Jang, M.: Dynamic light absorption of biomass-burning organic carbon photochemically aged under natural sunlight, Atmos. Chem. Phys., 14, 1517-1525, https://doi.org/10.5194/acp-14-1517-2014, 2014.

Zhu, J., Chen, Y., Shang, J., and Zhu, T.: Effects of air/fuel ratio and ozone aging on physicochemical properties and oxidative potential of soot particles, Chemosphere, 220, 883-891, https://doi.org/10.1016/j.chemosphere.2018.12.107, 2019. 